\title{
Jumlah Eosinofil pada Anak dengan Soil Transmitted Helminthiasis yang Berusia 6-10 Tahun
}

\author{
Reggy Harapan Baringin Silalahi, * Wistiani, ${ }^{*}$ Edi Dharmana** \\ *Departemen Pediatri, **Departemen Parasitologi Klinik Fakultas Kedokteran Universitas Diponegoro, \\ Semarang
}

Latar belakang. Kecacingan atau soil transmitted helminthes (STH) dan alergi keduanya merupakan masalah kesehatan dengan morbiditas yang cukup luas di berbagai negara. Kecacingan berkaitan dengan peningkatan eosinofil darah yang juga dipengaruhi oleh berbagai faktor termasuk alergi.

Tujuan. Membuktikan jumlah eosinofil darah pada anak usia 6 -10 tahun yang mengalami kecacingan (STH).

Metode. Desain studi observasional menggunakan cross sectional pada anak usia 6-10 tahun yang memenuhi kriteria inklusi. Subjek dipilih secara consecutive sampling di empat sekolah dasar di Semarang yang dipilih dengan purposive sampling. Dilakukan pemeriksaan fisik, tinggi badan, berat badan, mengisi kuisinoner International Study of Asthma and Allergies in Childhood (ISAAC), pemeriksaan mikroskopik feses dan jumlah eosinofil darah. Analisis statistik menggunakan uji Mann Whitney dan Pearson chi square.

Hasil. Di antara 74 anak, didapatkan 25 (33,8\%) dengan kecacingan (STH) dan 49 tidak kecacingan (66,2\%). Pada anak yang mengalami kecacingan (STH), nilai median eosinofil adalah 437,0 (123-1021) dan pada anak yang tidak kecacingan adalah 228,0 (72-1095) dengan nilai $\mathrm{p}=0,019$. Pada kecacingan $\mathrm{STH}$, nilai rasio prevalensi kejadian eosinofilia adalah 3,189 ( $\mathrm{p}=0,025$; 95\% CI 1,136-8,954). Nilai median eosinofil anak dengan alergi didapatkan 312,0 (111-799) dan pada anak yang tidak alergi didapatkan 251,0(72-1095) dengan nilai $\mathrm{p}=0,974$.

Kesimpulan. Jumlah eosinofil darah pada anak usia 6-10 tahun yang menderita kecacingan (STH) berbeda secara bermakna dengan anak yang tidak mengalami kecacingan. Sari Pediatri 2014;16(2):79-85.

Kata kunci: kecacingan, soil transmitted helminths, alergi, eosinofil

F aktor lingkungan berpengaruh kuat terhadap faktor risiko terjadinya kecacingan. ${ }^{1}$ Kecacingan yang paling umum disebabkan oleh infestasi cacing usus, yaitu cacing yang penyebarannya

Alamat korespondensi:

Dr. Reggy Harapan Baringin, SpA. Departemen Pediatri FK UNDIP/RSUP

Dr Kariadi Jl Dr Sutomo 16 Semarang. E-mail: aspirero@gmail.com melalui tanah (soil-transmitted helminths/STH). Parasit cacing STH termasuk Ascaris lumbricoides, Trichuris trichiura, dan cacing tambang (Ancylostoma duodenale dan Necator americanus) diperkirakan menginfeksi anak yang tinggal di pedesaan tropis dengan akses air bersih dan sanitasi yang buruk. Kecacingan karena STH sering bersifat kronis dan sering terdapat pada anak yang malnutrisi, kurus, retardasi intelektual, 
dan yang mengalami gangguan kognitif dalam bidang pendidikan. ${ }^{2-4}$

Prototype pertama kali dari terapi menggunakan cacing yang langsung digunakan untuk melawan penyakit immunologi adalah penelitian di Amerika Serikat dan beberapa negara maju di dunia. ${ }^{5}$ Dalam mempertahankan kelangsungan hidup untuk waktu yang panjang dalam tubuh manusia yang imunokompeten, organisme ini telah melakukan perkembangan strategi yang baik untuk bertahan hidup, termasuk kemampuan untuk mengatur dan memanipulasi sistem imun tubuh kita. ${ }^{6}$

Respon imun manusia terhadap kecacingan berkaitan dengan peningkatan kadar IgE, eosinofil jaringan dan mastocytosis, yang menstimulasiproduksi Th2, yaitu interleukin 4 (IL-4) dan interleukin 5 (IL5). Sementara itu, eosinofilia terjadi akibat efek sintesis IL-5 dari sel Th2. ${ }^{7}$ IL-5 merupakan sitokin paling penting pada transformasi dan pembentukan eosinofil dan bertindak sebagai aktivator eosinofil Salah satu penyebab peningkatan dari jumlah eosinofil adalah penyakit infeksi parasit seperti kecacingan. Eosinofil bekerja sebagai efektor dalam melawan kecacingan. ${ }^{8-10}$ Selain itu, eosinofil juga berperan penting dalam reaksi inflamasi alergi. ${ }^{10}$

Mekanisme imun pada cacing Ascaris adalah antigen Ascaris yang dihasilkan oleh cacing dewasa akan merangsang respon imun tubuh berupa sel $\mathrm{Th}_{2}$ yang akan menghasilkan eosinofilia, IgA, IgE, mastositosis dan mengeluarkan sekresi mukous melalui aktivasi sitokin IL-4, IL-5 dan IL- 13. Peningkatan eosinofil sendiri sangat dipengaruhi oleh IL-5 sebagai mediator, sedangkan IL-4 dan IL13 sangat memengaruhi perubahan fisiologi dalam saluran cerna seperti peningkatan permeabilitas mukosa dan kontraksi otot usus halus sehingga cacing akan didorong keluar dengan gejala berupa diare. ${ }^{11-14}$ Sementara itu, mekanisme imun tubuh melawan cacing Trichuris trichiura hampir sama pada cacing ascaris, tetapi antigen yang berperan adalah antigen dari larva Trichuris yang kemudian akan merangsang $\mathrm{Th}_{2}$ untuk memproduksi sitokin IL-5 yang sangat berperan sebagai mediator dari respon eosinofil. Pada Trichuris $s p p$, respon imun sel mast tidak berperan sama sekali untuk melawan cacing. ${ }^{11}$

Respon imun eosinofil terhadap cacing tambang sangat berperan baik dalam membunuh larva, maupun cacing tambang dewasa melalui respon imun sel Th2 yang kemudian akan menghasilkan IL-4,
IL-5 dan IL-13. Kemudian IL-4 akan merangsang terbentuknya IgE, IgG dan IgM, sedangkan IL-5 akan merangsang produksi eosinofil. Proses eosinofilia akan terjadi setelah larva cacing telah masuk ke sirkulasi darah tubuh dan akan tercapai antara 38 sampai 64 hari. $^{4,15,16}$

Hasil penelitian oleh Pearce $\mathrm{dkk}^{17}$ pada 56 negara maju untuk anak usia 13-14 tahun, terdapat peningkatan persentase asma $0,28 \%$ dan $0,18 \%$ pada 37 negara maju untuk anak usia 6-7 tahun setiap tahunnya. Sementara itu, pada daerah pedesaaan di negara berkembang, penyakit alergi relatif jarang dan beberapa daerah ini tampak berhubungan terbalik dengan prevalensi kecacingan yang relatif meningkat. 18,19

Penyakit alergi atau atopi sendiri sangat dipengaruhi oleh faktor genetik dari orang tua, meskipun tidak selalu, ditemukan lebih erat terkait dengan ibu daripada ayah. Pengamatan ini mungkin terkait dengan sejumlah mekanisme yang mendasarinya, termasuk cetakan gen, transmisi mitokondria, dan interaksi gen-lingkungan yang melibatkan lingkungan dalam rahim dan/atau pengaruh terhadap imunologi dan kandungan ASI. ${ }^{20}$ Pada penelitian yang dilakukan oleh LeMasters $\mathrm{dkk}^{21}$ terhadap bayi dari orang tua dengan atopi menunjukkan hasil $65,7 \%$ uji tusuk kulit positif pada usia 2 tahun.

Pengaruh terhadap eosinofilia dari pasien dengan kecacingan mungkin dapat bervariasi tergantung distribusinya, maturasi, kronisitas serta jenis parasitnya. ${ }^{10}$, ${ }^{22}$ Berdasarkan adanya pengaruh kecacingan yang dapat memengaruhi jumlah eosinofil darah, khususnya eosinofilia pada kecacingan yang juga dapat dipengaruhi alergi yang diuraikan di atas, memberikan landasan kepada peneliti untuk menyusun pertanyaan penelitian sebagai berikut.

Apakah jumlah eosinofil darah pada anak usia 6-10 tahun mengalami kecacingan soil transmitted helminthiasis berbeda dengan jumlah eosinofil darah pada yang tidak mengalami kecacingan?

\section{Metode}

Desain penelitian rancangan cross sectional yang dilakukan di Departemen Pediatri, khususnya Divisi Imunologi dan Divisi Infeksi dan Penyakit Tropik RSUP dr. Kariadi Semarang mulai bulan April 2013 sampai Juli 2013. Sekolah tempat subjek penelitan diperoleh 
secara purposive sampling dari data Dinas Kesehatan Semarang. Subjek penelitian dipilih dengan metode consecutive sampling, yaitu semua siswa dari 4 SD yang terpilih dengan kriteria inklusi anak SD usia 6-10 tahun dan mendapat persetujuan orang tua. Pasien yang memiliki riwayat penyakit kronis, immunocompromised, keganasan hematologi, hipoadrenalism, menderita infeksi protozoa atau kecacingan jenis lain serta memiliki riwayat pemakaian terapi antibiotik, antihistamin, kortikosteroid jangka panjang dalam 6 minggu terakhir dan obat anti cacing dalam 6 bulan terakhir tidak diikutsertakan dalam penelitian.

Selanjutnya, dilakukan anamnesis, pemeriksaan fisik, dan pemeriksaan laboratorium meliputi darah rutin, hitung jumlah eosinofil darah darah, mikroskopis feses dengan teknik apung untuk mencari telur cacing atau cacing STH dan kuisioner ISAAC (International Study of Asthma and Allergies in Childhood) tahap I untuk mencari adanya alergi pada subjek penelitian. Pengambilan darah vena dilakukan oleh tenaga medis. Pemeriksaan darah rutin dilakukan di laboratorium swasta, pemeriksaan mikroskopis feses dengan teknik apung di laboratorium Parasitologi Fakultas Kedokteran Universitas Diponegoro Semarang.

Analisis statistik dilakukan dengan uji Mann Whitney dan uji Pearson chi-square dengan menggunakan program komputer. Penelitian dilakukan setelah mendapat persetujuan dari Komisi Etik Penelitian Kesehatan (KEPK) Fakultas Kedokteran Universitas Diponegoro/RSUP dr. Kariadi Semarang dengan No.053/EC/FK/RSDK/2013.

\section{Hasil}

Pengambilan sampel secara consecutive sampling dilakukan pada bulan April 2013 sampai Juli 2013. Seratus empatpuluh empat anak dilakukan pemeriksaan fisik, pemeriksaan mikroskopis feses dengan teknik apung, dan kuesioner ISAAC tahap 1 yang diberikan kepada seluruh siswa kelas 2 sampai kelas 5 di tiga SD Negeri dan satu SD swasta. Tujuhpuluh empat $(51,4 \%)$ anak sesuai dengan kriteria inklusi dan eksklusi. Sebanyak Tujuhpuluh empat anak diikutsertakan. Dalam penelitian, didapatkan 25 anak dengan kecacingan soil transmitted helminthiasis (STH) dan 49 anak tidak kecacingan. Karakteristik demografis subjek tertera pada Tabel 1 di bawah ini.

Berdasarkan nilai rerata usia anak dalam bulan adalah $107,96 \pm 8,4$ pada anak dengan kecacingan STH dan 106,41 $\pm 9,78$ pada tidak kecacingan STH. Mayoritas jenis kelamin laki-laki $16(21,6 \%)$ anak dengan kecacingan STH dan $25(33,8 \%)$ tidak kecacingan STH. Mayoritas status gizi adalah gizi baik $23(31,1 \%)$ anak dengan kecacingan STH dan 42 (56,8\%) tidak kecacingan. Duapuluh (27\%) anak mendapat ASI eksklusif dengan kecacingan dan 39 $(52,7 \%)$ tidak kecacingan, seluruhnya dengan nilai $\mathrm{p}$ yang tidak bermakna (Tabel 1).

Karakteristik orangtua tertera pada Tabel 2 di bawah ini.

Tabel.1 Karakteristik demografis subjek penelitian

\begin{tabular}{lcc}
\hline \multirow{2}{*}{ Karakteristik } & $\begin{array}{c}\text { Kasus } \\
(\text { Kecacingan STH })\end{array}$ & $\begin{array}{c}\text { Kontrol } \\
\text { (Tanpa kecacingan STH) }\end{array}$ \\
\cline { 2 - 3 } Usia (bulan) & Mean ${ }_{ \pm}$SD, $\mathrm{n}(\%)$ & Mean \pm SD, $\mathrm{n}(\%)$ \\
Jenis kelamin & $107,96 \pm 8,4$ & $106,41 \pm 9,78$ \\
$\quad$ Laki-laki & $16(21,6)$ & $25(33,8)$ \\
$\quad$ Perempuan & $9(12,2)$ & $24(32,4)$ \\
Status gizi & & \\
$\quad$ Kurang & $2(2,7)$ & $7(9,5)$ \\
$\quad$ Baik & $23(31,1)$ & $42(56,8)$ \\
ASI eksklusif & & $39(52,7)$ \\
$\quad$ Ya & $20(27)$ & $10(13,5)$ \\
Tidak & $5(6,8)$ & \\
*uji Mann Whitney & & \\
** uji Pearson chi-square & &
\end{tabular}


Tingkat pendidikan ayah subjek paling banyak SMP dan SMA, masing-masing 7 (9,5\%) anak dengan kecacingan STH dan 20 (27\%) anak tidak kecacingan. Sementara itu, pendidikan ibu paling banyak SMA $9(12,2 \%)$ anak dengan kecacingan STH dan SD serta SMP masing-masing 15 (20,3\%) anak tidak kecacingan. Mayoritas pekerjaan ayah subjek adalah buruh 12 (16,2\%) anak kecacingan dan 19 (25,7\%) anak tidak kecacingan. Mayoritas ibu tidak bekerja $8(10,8 \%)$ anak tidak kecacingan dan 22 (29,7\%) anak tidak kecacingan (Tabel 2). Penghasilan keluarga mayoritas $<\mathrm{Rp} 1.000 .000,-$. Semuanya dengan nilai $\mathrm{p}$ yang tidak bermakna.
Nilai median jumlah eosinofil darah pada anak kecacingan STH adalah 437,0/ $\mu$ l (123-1021) dan yang tidak kecacingan adalah $228,0 / \mu l$ (72-1095). Berdasarkan uji Mann Whitney didapatkan hasil adanya perbedaan jumlah eosinofil darah yang bermakna antara kecacingan dengan yang tidak kecacingan ( $\mathrm{p}=0,019)$ (Tabel 3). Uji Pearson chi square didapatkan hasil $\mathrm{p}=0,025$ dengan $\mathrm{RP}=3,189 ; 95 \% \mathrm{CI}=1,136$ 8,954. Dapat disimpulkan bahwa kecacingan cenderung merupakan faktor risiko 3 kali untuk terjadinya eosinofilia.

Subjek penelitian 74 anak, terdiri dari 7 (28\%) anak memiliki alergi dengan kecacingan STH dan

Tabel 2. Karakteristik orang tua

\begin{tabular}{|c|c|c|}
\hline Karakteristik orang tua & $\begin{array}{c}\text { Kasus } \\
\text { (Kecacingan STH) } \\
\mathrm{n}(\%)\end{array}$ & $\begin{array}{c}\text { Kontrol } \\
\text { (Tanpa Kecacingan STH) } \\
\mathrm{n}(\%)\end{array}$ \\
\hline \multicolumn{3}{|l|}{ Pendidikan ayah } \\
\hline Tidak sekolah & $2(2,7)$ & $2(2,7)$ \\
\hline SD & $6(8,1)$ & $11(14,9)$ \\
\hline SMP & $7(9,5)$ & $20(27,0)$ \\
\hline SMA & $7(9,5)$ & $15(20,3)$ \\
\hline Sarjana (DIII/S1) & $3(4,1)$ & $1(1,4)$ \\
\hline \multicolumn{3}{|l|}{ Pekerjaan ayah } \\
\hline Wiraswasta & $4(5,4)$ & $10(13,5)$ \\
\hline PNS/ABRI & 0 & $1(1,4)$ \\
\hline Pegawai swasta & $8(10,8)$ & $13(17,6)$ \\
\hline Buruh & $12(16,2)$ & $19(25,7)$ \\
\hline Lainnya & $1(1,4)$ & $5(6,6)$ \\
\hline Tidak bekerja & 0 & $1(1,4)$ \\
\hline \multicolumn{3}{|l|}{ Pendidikan ibu } \\
\hline Tidak sekolah & $1(1,4)$ & $4(5,4)$ \\
\hline SD & $8(10,8)$ & $15(20,3)$ \\
\hline SMP & $5(6,8)$ & $15(20,3)$ \\
\hline SMA & $9(12,2)$ & $14(18,9)$ \\
\hline Sarjana (DIII/S1) & $2(2,7)$ & $1(1,4)$ \\
\hline \multicolumn{3}{|l|}{ Pekerjaan ibu } \\
\hline Wiraswasta & $3(4,1)$ & $6(8,1)$ \\
\hline PNS/ABRI & $111,4)$ & 0 \\
\hline Pegawai swasta & $5(6,8)$ & $7(9,5)$ \\
\hline Buruh & $6(8,1)$ & $10(13,5)$ \\
\hline Lainnya & $2(2,7)$ & $4(5,4)$ \\
\hline Tidak bekerja & $8(10,8)$ & $22(29,7)$ \\
\hline \multicolumn{3}{|l|}{ Penghasilan keluarga } \\
\hline$<$ Rp. 1 juta & $15(20,3)$ & $31(41,9)$ \\
\hline Rp. 1 juta -3 juta & $8(10,8)$ & $17(23,0)$ \\
\hline Rp. 3 juta -5 juta & $2(2,7)$ & $1(1,4)$ \\
\hline
\end{tabular}

* uji Kolmogrov-Smirnov 
Tabel 3. Kecacingan STH terhadap jumlah eosinofil darah

\begin{tabular}{lcccccc}
\hline \multirow{2}{*}{ Variabel } & \multicolumn{5}{c}{ Jumlah eosinofil darah } & \multirow{2}{*}{$\mathrm{p}$} \\
\cline { 2 - 6 } & Mean & SB & Median & Min. & Max. & \\
\hline Tanpa kecacingan & 321,80 & 226,334 & 228,0 & 72 & 1095 & \multirow{2}{*}{0,019} \\
Kecacingan & 462,28 & 271,076 & 437,0 & 123 & 1021 & \\
\hline
\end{tabular}

Tabel 4. Hubungan Kecacingan STH terhadap eosinofilia darah

\begin{tabular}{|c|c|c|c|c|c|c|}
\hline \multirow{2}{*}{ Kecacingan } & \multicolumn{2}{|c|}{ Kejadian eosinofilia } & \multirow{2}{*}{$\mathrm{p}$} & \multirow{2}{*}{ PR } & \multicolumn{2}{|c|}{$95 \% \mathrm{CI}$} \\
\hline & Normal & Eosinofilia & & & Bawah & Atas \\
\hline Tidak kecacingan & $38(74,5)$ & $11(47,8)$ & 0,025 & 3,189 & 1,136 & 8,954 \\
\hline Kecacingan & $13(25,5)$ & $12(52,2)$ & & & & \\
\hline
\end{tabular}

Tabel 5. Jumlah eosinofil darah berdasarkan kejadian alergi

\begin{tabular}{lcccccc}
\hline \multirow{2}{*}{ Variabel } & \multicolumn{5}{c}{ Jumlah eosinofil darah } & \multirow{2}{*}{ p } \\
\cline { 2 - 6 } & Mean & SB & Median & Min. & Max. & \\
\hline Tidak alergi & 374,25 & 262,366 & 251,0 & 72 & 1095 & \multirow{2}{*}{0,974} \\
Alergi & 352,53 & 207,396 & 312,0 & 111 & 799 & \\
\hline
\end{tabular}

$10(20,4 \%)$ memiliki alergi tanpa kecacingan STH. Tabel 5 menunjukkan nilai median jumlah eosinofil

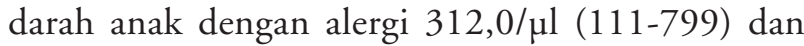

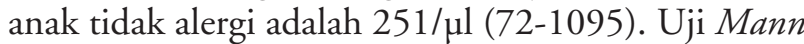
Whitney didapatkan hasil yang tidak bermakna pengaruh kejadian alergi terhadap jumlah eosinofil darah $(\mathrm{p}=0,974)$.

\section{Pembahasan}

Penelitian kami sesuai dengan penelitian yang dilakukan oleh Teo $\mathrm{dkk}^{23}$ yang meneliti 47 anak laki-laki dengan eosinofilia (kasus) dan 36 anak tanpa eosinofilia (kontrol). Mereka mendapatkan 43 anak (92\%) dari kelompok kasus mengalami kecacingan atau atopi atau keduanya, didapatkan adanya perbedaan yang bermakna jumlah eosinofil darah anak dengan kecacingan dibandingkan anak yang tidak kecacingan. Namun, mereka juga menyebutkan bahwa pada kelompok kasus tidak ada perbedaaan yang bermakna pada jumlah eosinofil darah antara anak yang kecacingan, alergi atau yang memiliki keduanya.

Pada kondisi normal tubuh memiliki jumlah eosinofil dalam darah 2\%-3\% dari total leukosit dan fungsinya sebagai sel efektor sitotoksik pada alergi dan infeksi parasit khususnya untuk mengeliminasi kecacingan. ${ }^{23}$ Eosinofilia terjadi akibat efek dari IL-5 yang merupakan refleksi dari sekresi sel $\mathrm{Th}_{2} \cdot{ }^{24}$
Eosinofilia darah berhubungan dengan kecacingan. Fungsi utama eosinofil adalah untuk perlindungan dalam melawan kecacingan dan eosinofil bertanggung jawab penuh pada patologi inflamasi kecacingan.

Penelitian Schulte $\mathrm{dkk}^{22}$ menunjukkan bahwa eosinofil yang tinggi didapatkan pada pasien kecacingan terutama dari negara-negara tropis. Diagnostik eosinofilia pada pasien kecacingan didapatkan dengan jumlah eosinofil yang ditentukan lebih dari 16\% dari hitung jenis leukosit. Adanya eosinofilia hanya merupakan satu dari alat penunjang diagnostik pada orang-orang yang terkena kecacingan.

Ustun $\mathrm{dkk}^{8}$ membandingkan eosinofilia pada 2 kelompok, kelompok pertama adalah subjek yang memiliki kecacingan, infeksi protozoa dan alergi sebanyak 23 orang. Kelompok kedua sebanyak 21 orang tanpa infeksi. Pada kelompok pertama didapatkan 15 orang dengan kecacingan, 8 orang dengan infeksi protozoa, semuanya dengan gejala diare. Pada penelitian tersebut tidak didapatkan perbedaan hitung jenis eosinofilia antara kedua kelompok hal ini dimungkinkan karena pada penelitian ini kedua kelompok memiliki gejala alergi. Baik kecacingan, alergi, maupun infeksi protozoa ketiganya mampu menginduksi terbentuknya IL-5 yang nantinya sebagai sitokin mediator terbentuknya eosinofilia. ${ }^{10}$

Medeiros $\mathrm{dkk}^{26}$ meneliti 101 pasien usia 12 sampai 21 tahun menyatakan bahwa peningkatan $\mathrm{IgE}$ dan jumlah eosinofil tidak hanya berkaitan dengan alergi, 
tetapi juga berkaitan dengan kecacingan. Mereka mendapatkan hasil yang tidak bermakna pengaruh kecacingan terhadap jumlah eosinofil darah dikaitkan dengan alergi. Didapatkan beberapa pasien dengan kecacingan ataupun alergi yang memiliki jumlah eosinofil 1 yang normal. Perhitungan eosinofil bisa didapatkan jumlah yang normal pada kecacingan karena pematangan dan usia eosinofil sangat tergantung dari kadar IL-5 dan yang menyebabkan eosinofil lebih responsif terhadap granulosit dan macrophage colony-stimulating factor (GM CSF). Kadar eosinofil yang tinggi lebih sering ditemukan pada kecacingan yang kronis.

Pada penelitian ini, di antara 74 subjek didapatkan 7 anak memiliki alergi dengan kecacingan STH dan 10 anak alergi tanpa kecacingan STH, tidak didapatkan perbedaan jumlah eosinofil darah terhadap kejadian alergi. Hal ini sesuai dengan penelitian yang dilakukan oleh Teo $\mathrm{dkk}^{23}$ yang meneliti 47 anak laki-laki dengan eosinofilia, 92\% di antaranya mengalami kecacingan atau atopi atau keduanya. Teo dkk mendapatkan bahwa peningkatan jumlah eosinofil darah lebih tinggi pada anak kecacingan daripada anak dengan alergi. Ini juga didukung oleh Medeiros $\mathrm{dkk}^{26}$ yang meneliti hubungan total serum IgE, jumlah eosinofil absolut dan antiAscaris IgE pada anak dengan asma dan atau rhinitis alergi. Menurut penelitian tersebut didapatkan $49,5 \%$ pasien dengan alergi saluran napas menunjukkan jumlah eosinofil normal. Eosinofilia dan peningkatan serum IgE merupakan indikator alergi dan kecacingan, tetapi eosinofilia sendiri merupakan mekanisme imun utama untuk melawan kecacingan., 9, 10

Keterbatasan penelitian ini adalah tidak dilakukan pemeriksaan IL-5, anti Ascaris IgE dan rancangan penelitian ini berupa cross sectional.

\section{Kesimpulan}

Jumlah eosinofil darah pada anak usia 6-10 tahun yang menderita kecacingan (STH) berbeda secara bermakna dengan anak yang tidak mengalami kecacingan. Melihat tingginya morbiditas dan kelainan alergi pada anak di daerah yang berisiko tinggi, diusulkan untuk pemeriksaan skrining feses dan mengobatinya bila betul-betul terinfeksi. Perlu penelitian mengenai perbedaan jenis cacing terhadap kejadian eosinofilia sehingga dapat dilakukan prevensi terhadap kejadian infestasi dan eradikasi cacing tersebut.

\section{Daftar pustaka}

1. Weinstock JV, Elliott DE. Helminths and the IBD hygiene hypothesis. Tufts New England Medical Center 2009; 15:128-33.

2. Cooper PJ. Interactions between helminth parasites and allergy. Curr Opin Allergy Clin Immunol 2009;9:29-37.

3. Lynch NR, Hagel IA, Palenque ME, Prisco MCD, Escudero JE, Corao L, dkk. Relationship between helminthic infection and $\operatorname{IgE}$ response in atopic and nonatopic children in a tropical environment. J Allergy Clin Immunol 1998;101:217-21.

4. Bethony J, Brooker S, Albonico M, Geger SM, Loukas A, Diemert D, dkk. Soil-transmitted helminth infection: ascariasis, trichuriasis, and hookworm. Lancet 2006;367:1521-32.

5. Pontre EV, Rizzo JA, Cruz AA. Interrelationship among asthma, atopy and helminth infections. J Bras Pneumol 2007;33:335-42.

6. Helmby H. Helminths and our immune system : friend or foe? Parasitology Intenational 2009;58:121-7.

7. Moreau E, Chauvin A. Immunity against helminths: interactions with the host and the intercurrent infections. J Biomed Biotech 2010;2010:1-10.

8. Ustun S, Turgay N, Delibas SB, Ertabaklar H. Interleukin (IL) 5 level and eosinophilia in patients with intestinal parasitic disease. World J Gastroenterol 2004;10:3643-6.

9. Anthony RM, Rutitzky LI, Urban JF, Stadecker MJ, Gause WC. Protective immune mechanisms in helminth infection. Nat Rev Immunol 2007;7:975-87.

10. Nutman TB. Evaluation and differential diagnosis of marked, persistent eosinophilia. Immunol Allergy Clin North Am 2007;27:529-49.

11. Bradley JE, Jackson JA. Immunity, immunoregulation and the ecology of trichuriasis and ascariasis. Parasite Immunol 2004;26:429-41.

12. Cooper PJ, Chico ME, Sandoval C, Espinel I, Guevara A, Kennedy MW, dkk. Human infection with ascariasis lumbricoides is associated with a polarized cytokine response. J Infect Dis 2000;182:1207-13.

13. Turner JD, Faulkner H, Kamgno J, Corment F, Snick JV, Else KJ, dkk. Th2 cytokines are associated with reduced worm burdens in human intestinal helminth infection. J Infect Dis 2003;188:1769-75.

14. King EM, Kim HT, Dang NT, Michael E, Drake L, Needham C, dkk. Imunno-epidemiology of ascaris lumbricoides infection in a high transmission community: antibody responses and theri impact on current and future 
infection intensity. Parasite Immunol 2005;27:89-96.

15. Geiger SM, Caldas IR, Glone BEM, Campi-Azevedo AC, Oliveira LMD, Brooker S, dkk. Stage-spesific immune responses in human Necator americanus infection. Parasite Immunol. 2007;29:347-58.

16. Loukas A, Prociv P. Immune response in hookworm infection. Clin Microbiol Rev 2001;14:689-703.

17. Pearce N, Ait-Khaled N, Beasly R, Malool J, Keil U, Mitchell E, dkk. Worldwide trends in the prevalence of asthma symptoms : phase III of the tnternational study of asthma and allergies in childhood (ISAAC). Thorax J BMJ 2007;62:758-66.

18. Cooper PJ, Barreto ML, Rodrigues LC. Human allergy and geohelminth infection : a review of the literature and a proposed conceptual model to guide the investigation of possible causal associations. Brit Med Bull Ad Acc 2007;4:1-16.

19. Smits HH, Everts B, Hartgers FC, Yazdanbakhsh M. Chronic helminth infections protect against allergic disease by active regulatory processes. Curr Allergy Asthma Rep 2010;10:3-12.

20. Morar N, Derm FC, Willis-Owen SAG, Moffatt MF.
The genetics of atopic dermatitis. J Allergy Clin Immunol 2006;118:24-34.

21. LeMasters GK, Wilson K, Leven L, Biagini J, Ryan P, Lockey JE, dkk. High prevalence of aeroallergen sensitization among infants of atopic parents. J Pediatr 2006;194:505-11.

22. Schulte C, Krebs B, Jelinek T, Nothdurft HD, Sonnenburg Fv, Loscher T. Diagnostic significance of blood eosinophilia in returning travelers. Brief Reports 2002;34:407-11.

23. Teo CG, Singh M, Ting WC, Ho LC, Ong YW, Seet LC. Evaluation of the common conditions associated with eosinophilia. J Clin Pathol 1985;38:305-8.

24. Meeusen EN, Balic A. Do eosinophils have role in the killing of helminth parasites? Parasitol Today 2000;16:95-101.

25. Dombrowicz D, Capron M. Eosinophils, allergy and parasites. Curr Opin Immunol 2001;13:716-20.

26. Medeiros D, Silva AR, Rizzo JA, Motta ME, Oliveira FHBd, Sarinho ES. Total IgE level in respiratory allergy: study of patients at high risk for helminthic infection. J de Pediatr 2005;82:255-9. 